\title{
Interfacial Reactions of Zn-Al Alloys with Na Addition on Cu Substrate During Spreading Test and After Aging Treatments
}

\author{
Tomasz Gancarz, Janusz Pstruś, and Katarzyna Berent
}

\author{
(Submitted October 28, 2015; in revised form April 12, 2016; published online April 26, 2016)
}

\begin{abstract}
Spreading tests for $\mathrm{Cu}$ substrate with $\mathrm{Zn}$-Al eutectic-based alloys with $0.2,0.5$, and $1.0 \mathrm{wt} \%$ of $\mathrm{Na}$ were studied using the sessile drop method in the presence of QJ201 flux. Spreading tests were performed for 1 , $3,8,15,30$, and $60 \mathrm{~min}$ of contact, at the temperatures of $475,500,525$, and $550{ }^{\circ} \mathrm{C}$. After cleaning the flux residue from solidified samples, the spreading area of $\mathrm{Zn}-\mathrm{Al}+\mathrm{Na}$ on $\mathrm{Cu}$ was determined in accordance with ISO 9455-10:2013-03. Selected, solidified solder-substrate couples were cross-sectioned and subjected to scanning electron microscopy of the interfacial microstructure. The experiment was designed to demonstrate the effect of $\mathrm{Na}$ addition on the kinetics of formation and growth of $\mathrm{CuZn}, \mathrm{Cu}_{5} \mathrm{Zn}_{8}$, and $\mathrm{CuZn}$ phases, which were identified using $x$-ray diffraction and energy-dispersive spectroscopy analysis. The addition of $\mathrm{Na}$ to eutectic $\mathrm{Zn}-\mathrm{Al}$ caused the spreading area to decrease and the thickness of intermetallic compound layers at the interface to reduce. Samples after the spreading test at $500{ }^{\circ} \mathrm{C}$ for 1 min were subjected to aging for 1,10 , and 30 days at 120,170 , and $250^{\circ} \mathrm{C}$. The greater thicknesses of IMC layers were obtained for a temperature of $250{ }^{\circ} \mathrm{C}$. With increasing $\mathrm{Na}$ content in $\mathrm{Zn}-\mathrm{Al}+\mathrm{Na}$ alloys, the thickness reduced, which correlates to the highest value of activation energy for $\mathrm{Zn}-\mathrm{Al}$ with $1 \% \mathrm{Na}$.
\end{abstract}

Keywords aging, IMCs, lead-free solder, spreading test, $\mathrm{Zn}-\mathrm{Al}-\mathrm{Na}$

\section{Introduction}

The addition of $\mathrm{Na}$ to eutectic $\mathrm{Zn}-\mathrm{Al}$ produces the $\mathrm{NaZn}_{13}$ precipitates that caused increased mechanical properties of cast alloys (Ref 1). The alloying additions have a significant impact on properties of cast alloys and on the soldering process, as shown in previous studies for $\mathrm{Ag}$ ( $\operatorname{Ref} 2), \mathrm{Cu}(\operatorname{Ref} 3,4), \operatorname{In}(\operatorname{Ref} 5)$, and Sn (Ref 6). The addition of alloying elements to Zn-Al should block the growth of intermetallic compounds (IMCs) at the interface of liquid solder and in the $\mathrm{Cu}$ substrate. The optimal thickness of IMCs, in the $\mathrm{CuZn}, \mathrm{Cu}_{5} \mathrm{Zn}_{8}$, and $\mathrm{CuZn}_{4}$ phases, reduce diffusion of $\mathrm{Cu}$ to the solder. The $\mathrm{Zn}$ bonded with $\mathrm{Na}$ formed $\mathrm{NaZn}_{13}$ precipitates which could reduce the thickness of IMC layer at the interface. A similar effect was observed with the addition of $\mathrm{Ag}$ content to $\mathrm{Zn}-\mathrm{Al}$, which confirms the assumption that precipitates of $\mathrm{AgZn} \mathrm{n}_{3}$ are produced with $\mathrm{Zn}$ and reduce the thickness of IMC

This article is an invited submission to JMEP selected from presentations at the Symposium "Wetting and High-Temperature Capillarity," belonging to the Topic "Joining and Interfaces" at the European Congress and Exhibition on Advanced Materials and Processes (EUROMAT 2015), held September 20-24, 2015, in Warsaw, Poland, and has been expanded from the original presentation.

Tomasz Gancarz and Janusz Pstruś, Institute of Metallurgy and Materials Science, Polish Academy of Sciences, 30-059 Kraków, Poland; and Katarzyna Berent, AGH University of Science and Technology, Academic Centre for Materials and Nanotechnology, 30-059 Kraków, Poland. Contact e-mail: tomasz.gancarz@imim.pl. layer at the interface ( $\operatorname{Ref} 2)$. In case of $\mathrm{Cu}$ additions to $\mathrm{Zn}-\mathrm{Al}$, the $\mathrm{Cu}$ and $\mathrm{Zn}$ formed $\mathrm{CuZn}, \mathrm{Cu}_{5} \mathrm{Zn}_{8}$, and $\mathrm{CuZn} \mathrm{n}_{4} \mathrm{IMCs}$, although this had no impact on the growth of IMC layers at the interface (Ref 3, 4). Even, Kang et al. (Ref 7) observed that increasing Al and $\mathrm{Cu}$ concentrations in solder caused the spreading area to reduce. As expected, the increasing wettability and IMC layer growth at the interface, caused by alloying elements (Ref 2-7), improved the mechanical properties of the joint. The possibility of using $\mathrm{Zn}-\mathrm{Al}$ alloys to $\mathrm{Al} / \mathrm{Cu}$ (Ref 8), $\mathrm{Al} / \mathrm{Mg}$ (Ref 9), Al/steel (Ref 10), and $\mathrm{Cu} / \mathrm{Cu}$ (Ref 11) joints, as solders, extends the potential applications in industry. However, there have been few studies on the influence of time, temperature, and alloying elements in the soldering process on spreadability and the growth of the IMC layer at the interface. The study of $\mathrm{Zn}-\mathrm{Al}$ with Ag content (Ref 2 ) and $\mathrm{Zn}-\mathrm{Al}$ with $\mathrm{Cu}$ content (Ref 4, 12), on $\mathrm{Cu}$ substrate, confirms that a small addition of $\mathrm{Ag}$ or $\mathrm{Cu}$ reduces the thickness of IMC layers at the interface. Increasing time and temperature caused increasing diffusion of $\mathrm{Cu}$ to solder and the growth of IMC layers, most notably regarding the growth of the $\mathrm{Cu}_{5} \mathrm{Zn}_{8}$ layer, which is characterized by the lowest Gibbs free energy (Ref 2). Moreover, the $\mathrm{Al}_{4} \mathrm{Cu}_{9}$ phase formed at the interface inside the $\mathrm{Cu}_{5} \mathrm{Zn}_{8}$ layer which is in accordance with the phase diagram of the Al-Cu-Zn system (Ref 13).

The aim of this study is to demonstrate the effect of $\mathrm{Na}$ addition on the kinetics of the formation and growth of the $\mathrm{CuZn}, \mathrm{Cu}_{5} \mathrm{Zn}_{8}$, and $\mathrm{CuZn}_{4}$ phases, during the spreading test and after aging treatments.

\section{Experimental}

The $\mathrm{Zn}-\mathrm{Al}$ cast alloys with $0.2,0.5$, and $1.0 \mathrm{wt} . \%$ of $\mathrm{Na}$ (Ref 1) were studied using the sessile drop method in the presence of QJ201 flux. The experiments without flux were unsuccessful, 
as the surface of the solder was oxidized, resulting in a failure to connect with $\mathrm{Cu}$ substrate. Therefore, flux QJ201 from powder, consisting of $\mathrm{KCl} 50$ wt.\%, $\mathrm{LiCl} 32 \mathrm{wt} . \%, \mathrm{NaF}$ $10 \mathrm{wt} . \%$, and $\mathrm{ZnCl}_{2} 8 \mathrm{wt} . \%$, was applied for the purposes of protection and oxide removal. Wetting tests were performed after $1,3,8,15,30$, and 60 min of contact, at the temperatures of $475,500,525$, and $550^{\circ} \mathrm{C}$. As described in Ref 2, the spreading area of $0.5 \mathrm{~g}$ samples of $\mathrm{Zn}-\mathrm{Al}-\mathrm{Na}$ solder was calculated after cleaning the flux residue from solidified samples. The spreading area of $\mathrm{Zn}-\mathrm{Al}+\mathrm{Na}$ alloys on $\mathrm{Cu}$ substrate was determined in accordance with ISO 945510:2013-03. Selected solder/substrate couples were cut perpendicular to the plane of the interface using a diamond wire saw, then mounted in conductive resin, ground, polished, and subjected to microstructure and elemental analyses using scanning electron microscopy (SEM) coupled with energydispersive spectrometry (EDS) and x-ray diffraction (XRD) analysis to study the interfacial microstructure and IMCs occurring at the interface. For all samples, three measurements were made at different areas to improve counting statistics and to check the homogeneity of the joints. The XRD measurement was performed in the center of the joint and on the opposite edges. The stress investigation was carried out with the basic assumptions known from the traditional $\sin _{2} \psi$ method, with the use of the D8 Discover Bruker diffractometer equipped with a parallel-beam primary optics PolyCap system completed a pinhole collimator $(1.0 \mathrm{~mm}$ aperture) for $\mathrm{Cu} \mathrm{K \alpha}$ radiation $(\lambda=1.7903 \AA)$ and a linear position-sensitive detector LynxEye (range $2.6^{\circ}$ on $2 \theta$ ), capable of working in a parallel secondary beam configuration with the use of Soller collimators. The accelerating voltage and the applied current were $40 \mathrm{kV}$ and $35 \mathrm{~mA}$, respectively. The thickness of the IMC layer $(d)$ is dependent on the growth rate $(k)$ and growth time $(t)$ versus exponential factor $(n)$ :

$d=k(t)^{n}$.

The growth rate for interface migration is described by an Arrhenius-type equation as follows:

$k=k_{0} \exp \left(-\frac{Q}{R T}\right)$

where $k_{0}, Q, R$, and $T$ represent the migration rate constant, the activation energy, the universal gas constant, and the absolute temperature, respectively. Cross-sections after spreading test at $500{ }^{\circ} \mathrm{C}$ for $1 \mathrm{~min}$ were subjected to aging for 1,10 , and 30 days at 120,170 , and $250^{\circ} \mathrm{C}$. The growth rate and activation energy of the $\mathrm{Cu}_{5} \mathrm{Zn}_{8}$ layer in the solid state were determined.

\section{Results and Discussion}

\subsection{Reaction of Solders with Substrate Interactions}

The characteristics of cast $\mathrm{Zn}-\mathrm{Al}+\mathrm{Na}$ alloys (Ref 1) undergoing the soldering process on a $\mathrm{Cu}$ substrate were determined in relation to time and temperature dependencies. The spreading areas of $\mathrm{Zn}-\mathrm{Al}+\mathrm{Na}$ alloys for spreading test at $500{ }^{\circ} \mathrm{C}$ after $1,3,8,15,30$, and $60 \mathrm{~min}$ of contact and at the temperatures of $475,500,525$, and $550{ }^{\circ} \mathrm{C}$ after $8 \mathrm{~min}$ are shown in Fig. 1(a) and (b), respectively. Compared to eutectic $\mathrm{Zn}-\mathrm{Al}$, an increased spreading area was observed for $\mathrm{Zn}-\mathrm{Al}$ alloys with $\mathrm{Na}$ content. The increased $\mathrm{Na}$ content in $\mathrm{Zn}-\mathrm{Al}$ alloys did not cause the spreading area to increase for similar time and temperature dependencies. However, the spreading area increased as time (Fig. 1a) and temperature (Fig. 1b) increase. For $\mathrm{Zn}-\mathrm{Al}+\mathrm{Na}$ alloys, the effect was greater for longer times (30 and $60 \mathrm{~min}$ ) and higher temperatures (525 and $550{ }^{\circ} \mathrm{C}$ ), compared to eutectic $\mathrm{Zn}-\mathrm{Al}$. Although the addition of $\mathrm{Ag}$ to $\mathrm{Zn}-\mathrm{Al}$ alloys caused the formation of $\mathrm{AgZn} \mathrm{n}_{3} \mathrm{IMCs}$, as $\mathrm{Na}$ content $\mathrm{NaZn}_{13}$, the spreading area of the $\mathrm{Zn}-\mathrm{Al}+\mathrm{Ag}$ alloys was lower compared to eutectic $\mathrm{Zn}-\mathrm{Al}$ (Ref 2). The spreading area of the $\mathrm{Zn}-\mathrm{Al}+\mathrm{Cu}$ alloys (Ref 4) was similar to or lower than that of eutectic $\mathrm{Zn}-\mathrm{Al}$, although IMCs of $\mathrm{Cu}_{5} \mathrm{Zn}_{8}$ and $\mathrm{CuZn}_{4}$ were formed inside the solder and at the interface during spreading tests. Additions of $\mathrm{Ag}, \mathrm{Cu}$, and $\mathrm{Na}$ to $\mathrm{Zn}-\mathrm{Al}$ alloys caused the formation of IMCs, but in the spreadability tests the most important were the surface active elements, which shows Na. Flux could have a decisive impact on the spreading area. Flux QJ201 was used for Zn-Al + Na, and flux Alu33 for Zn$\mathrm{Al}+\mathrm{Ag}$ and $\mathrm{Zn}-\mathrm{Al}+\mathrm{Cu}$.

The microstructures of $\mathrm{Zn}-\mathrm{Al}$ with $1.0 \% \mathrm{Na}$ alloys on $\mathrm{Cu}$ substrates after the spreading test at a temperature of $500{ }^{\circ} \mathrm{C}$ for the times of (a) 1, (b) 3, (c) 8, (d) 15, (e) 30, and (f) 60 min are presented in Fig. 2. At the interface, the three IMCs $(\mathrm{CuZn}$,
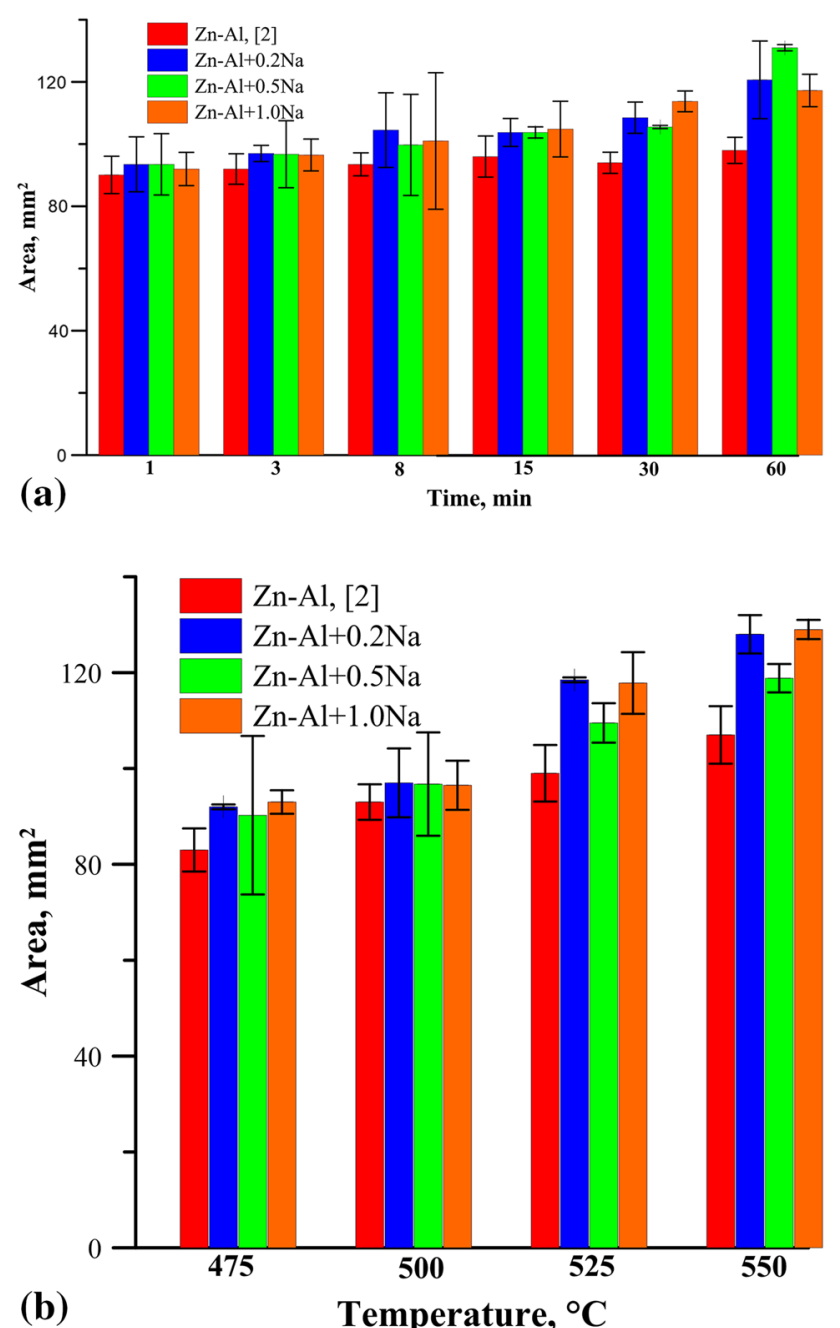

Fig. 1 Spreading area of $\mathrm{Zn}-\mathrm{Al}$ alloys with $\mathrm{Na}$ additions: (a) time and (b) temperature dependencies 

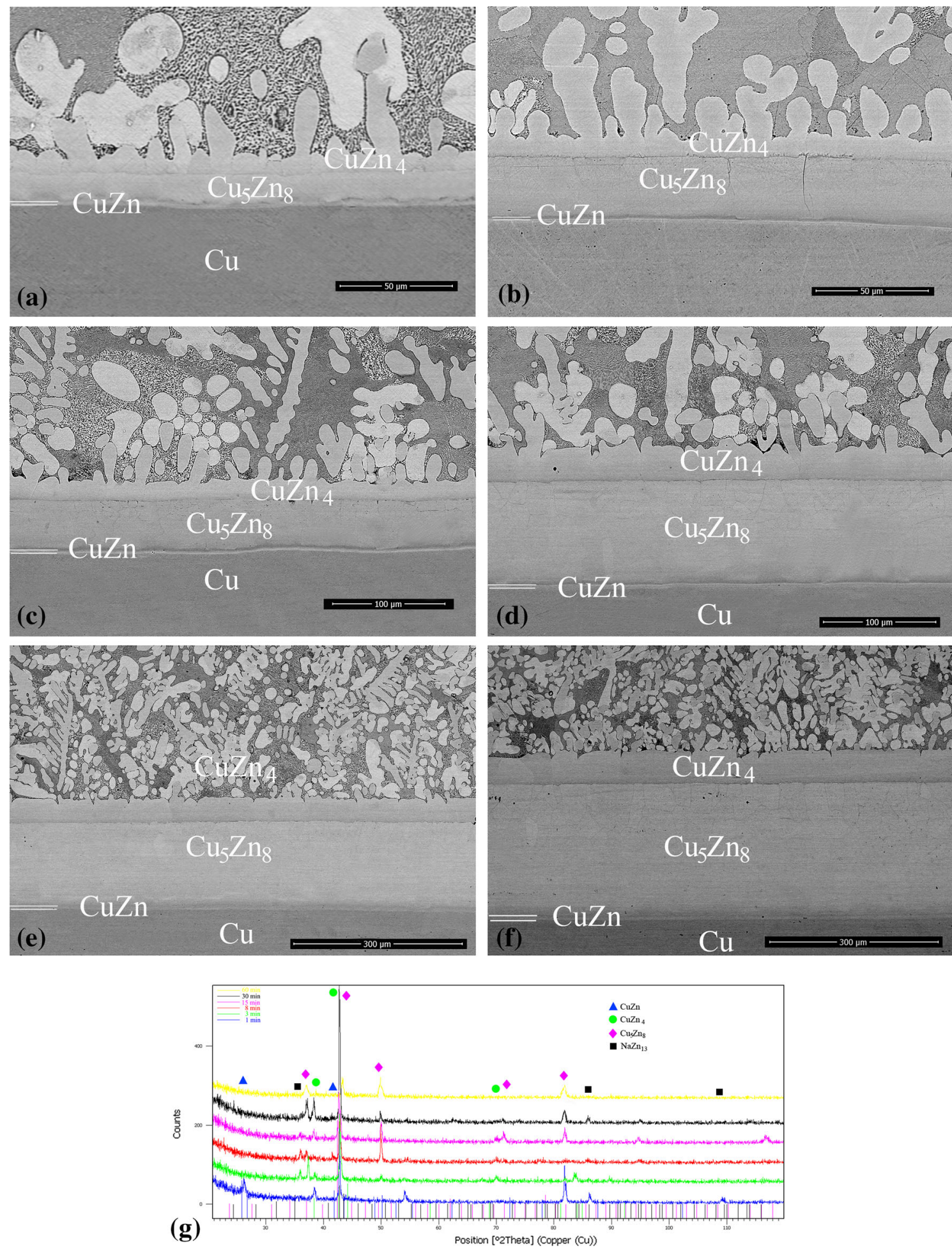

Fig. 2 Microstructures of interfaces on the cross-sections of $\mathrm{Zn}$-Al with $1.0 \% \mathrm{Na}$ alloys on $\mathrm{Cu}$ substrates after spreading test at a temperature of $500{ }^{\circ} \mathrm{C}$ for a time of (a) $1 \mathrm{~min}$, (b) $3 \mathrm{~min}$, (c) $8 \mathrm{~min}$, (d) $15 \mathrm{~min}$, (e) $30 \mathrm{~min}$, and (f) $60 \mathrm{~min}$, and (g) XRD analysis results (starting from $60 \mathrm{~min}$ on the top to $1 \mathrm{~min}$ at the figure's bottom)

$\mathrm{Cu}_{5} \mathrm{Zn}_{8}$, and $\mathrm{CuZn}$ ) were observed from the $\mathrm{Cu}$ substrate side, for all times. The formation of IMCs was confirmed by XRD analysis (Fig. 2g). With increasing time, the IMCs grew, with the highest growth for the $\mathrm{Cu}_{5} \mathrm{Zn}_{8}$ phase, which was observed on the microstructure and in the peaks in XRDs. The CuZn phase was a thin layer on the $\mathrm{Cu}$ substrate as observed in Ref 2,
4, 8 and confirmed by Liu et al. (Ref 14). Next, the $\mathrm{Cu}_{5} \mathrm{Zn}_{8}$ phase, of greater thickness than the top layer, shows the fast path of $\mathrm{Cu}$ diffusion, which is also observed in $\mathrm{Zn}-\mathrm{Al}$ with $\mathrm{Ag}$ and $\mathrm{Cu}$ alloys ( $\operatorname{Ref} 2,4,7)$. The last layer is the $\mathrm{CuZn}_{4}$ phase, at the top of which scallops were formed which detached and moved to the solder. Microstructure and character of changes, 
similar to those obtained for $\mathrm{Zn}-\mathrm{Al}+\mathrm{Na}$ alloys, were observed for $\mathrm{Ag}(\operatorname{Ref} 2)$ and $\mathrm{Cu}(\operatorname{Ref} 4,7)$ additions to $\mathrm{Zn}-\mathrm{Al}$ alloys. From the data of XRD analysis (Fig. 2g), for $1 \mathrm{~min}$ the $\mathrm{CuZn}$, $\mathrm{CuZn}_{4}$, and $\mathrm{Cu}_{5} \mathrm{Zn}_{8}$ phases are observed, and with increasing time the participation is changed. For $60 \mathrm{~min}$, the peaks of $\mathrm{Cu}_{5} \mathrm{Zn}_{8}$ phase are increased, which is in line with microstructural observation and literature.

In Fig. 3, the dependencies of IMC thickness over time for (a) 0.2 wt. $\%$, (b) 0.5 wt. $\%$, and (c) 1.0 wt. $\%$ Na addition to Zn$\mathrm{Al}$ alloy are presented. The thickness of IMCs for all $\mathrm{Zn}$ $\mathrm{Al}+\mathrm{Na}$ alloys looks similar, with the effect of adding $\mathrm{Na}$ to eutectic $\mathrm{Zn}$-Al being a slightly reduced thickness of the IMC layers compared to eutectic $\mathrm{Zn}-\mathrm{Al}$ (Ref 2). The $\mathrm{Cu}_{5} \mathrm{Zn}_{8}$ showed the highest growth, followed by $\mathrm{CuZn}_{4}$ and then $\mathrm{CuZn}$. The character and rate of growth are correlated to parameter " $n$ " as a coefficient of growth, where $n \ll 0.5$ represents the grain boundary, $n=0.5$ represents the volume diffusion, and $n=1$ represents the chemical reaction. The parameter " $n$ " is determined from (1). According to $n$ calculated for the $\mathrm{CuZn}$, $\mathrm{Cu}_{5} \mathrm{Zn}_{8}$, and $\mathrm{CuZn}$ phases, i.e., $n_{\mathrm{Cu}_{5} \mathrm{Zn}_{8}}>n_{\mathrm{CuZn}_{4}}>n_{\mathrm{CuZn}}$, which corresponds to the character of growth, the $\mathrm{Cu}_{5} \mathrm{Zn}_{8}$ phase grows by mixed volume diffusion and chemical reaction, and the $\mathrm{CuZn}$ and $\mathrm{CuZn}$ 作 $\mathrm{Zn}$-Al alloy with Na content, the coefficients $n$ and $k$ for the $\gamma$ $\mathrm{Cu}_{5} \mathrm{Zn}_{8}$ phase were of the same level $(0.75$ and 0.5 for each alloy, respectively), which means that increased $\mathrm{Na}$ content in the alloys has no influence on how the $\gamma$ phase is created. There was a similar effect for $\beta-\mathrm{CuZn}$, for which $n$ and $k$ were on the same level (around 0.44 and 0.22 for each of the alloys, respectively). For the $\varepsilon-\mathrm{CuZn} n_{4}$ phase, the coefficient $n$ was around 0.5 , but $k$ was reducing with increased $\mathrm{Na}$ content in the alloys $(1.75,1.10$, and 0.91 for $0.2,0.5$, and 1.0 wt. $\% \mathrm{Na}$, respectively). The growth of the $\beta$ and $\varepsilon$ phases was controlled by volume diffusion. The obtained values of $k$ and $n$ for $\mathrm{Zn}$ $\mathrm{Al}+\mathrm{Na}$ alloys were similar for the $\beta$ and $\varepsilon$ phases, as reported for $\mathrm{Zn}-\mathrm{Al}+\mathrm{Ag}(\operatorname{Ref} 2)$ and $\mathrm{Zn}-\mathrm{Al}+\mathrm{Cu}(\operatorname{Ref} 12)$. In the case of $\mathrm{Zn}-\mathrm{Al}+\mathrm{Ag}(\operatorname{Ref} 2)$ and $\mathrm{Zn}-\mathrm{Al}+\mathrm{Cu}(\operatorname{Ref} 12)$, the coefficient $n$ was definite at 0.5 for all phases, and growth was controlled by volume diffusion. However, for the $\gamma$ phase the coefficient $n$ was slightly higher (0.87 for $\mathrm{Zn}-\mathrm{Al}+\mathrm{Ag}(\operatorname{Ref} 15))$, but $k$ was much lower (around 0.2). Growth was controlled by mixed volume diffusion and chemical reaction, as for $\mathrm{Zn}-\mathrm{Al}+\mathrm{Ag}+$ $\mathrm{Cu}$, but the thickness of the IMC layers was slightly lower (Ref 15). However, in Ref 15 the soldering process was conducted for joints $\mathrm{Cu} /$ solder/ $\mathrm{Cu}$, which could have impacted the values of $k$ and $n$. Therefore, the growth of IMCs for $\mathrm{Zn}-\mathrm{Al}+\mathrm{Ag}$ and $\mathrm{Zn}-\mathrm{Al}+\mathrm{Cu}$ in Ref 15 was different compared to $\mathrm{Zn}-\mathrm{Al}+\mathrm{Ag}$ (Ref 2) and $\mathrm{Zn}-\mathrm{Al}+\mathrm{Cu}$ (Ref 12). In the present study, it was observed that, in the beginning, the spreading test shows that the $\mathrm{Cu}$ substrate dissolved quickly by the liquid solder, followed by the formation of an IMC layer at the interface, so temperature should have a decisive impact on the amount of $\mathrm{Cu}$ substrate dissolved. The microstructures of $\mathrm{Zn}-\mathrm{Al}$ with $0.5 \% \mathrm{Na}$ on a $\mathrm{Cu}$ substrate after soldering for $8 \mathrm{~min}$ at the temperatures of (a) $475{ }^{\circ} \mathrm{C}$, (b) $500{ }^{\circ} \mathrm{C}$, (c) $525{ }^{\circ} \mathrm{C}$, and (d) $550{ }^{\circ} \mathrm{C}$ are presented in Fig. 4. The formation of IMCs at the interface was confirmed by XRD analysis (Fig. 4e). For the 475 and $500{ }^{\circ} \mathrm{C}$, the peaks for $\mathrm{CuZn}$ and $\mathrm{CuZn}_{4}$ are observed in XRDs, moving to higher temperature 525 and $550{ }^{\circ} \mathrm{C}$, the participation for $\mathrm{CuZn}_{4}$ and $\mathrm{Cu}_{5} \mathrm{Zn}_{8}$ phases increased. With the increasing temperature, the $\beta, \varepsilon$, and $\gamma$ phase layers grow, with the $\gamma$ phase having the greatest thickness. The highest growth of
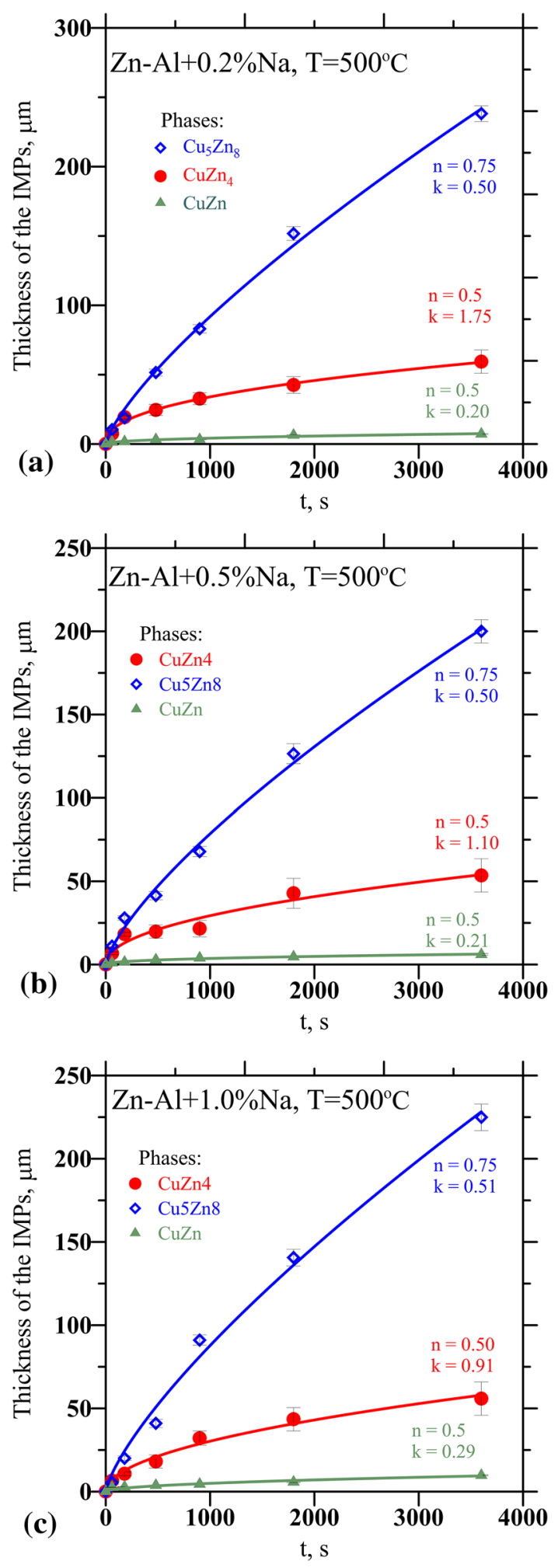

Fig. 3 Dependencies of IMC layer thickness with time for (a) 0.2 wt. $\%$, (b) 0.5 wt. $\%$, and (c) 1.0 wt.\% Na addition to $\mathrm{Zn}-\mathrm{Al}$ alloy

the $\gamma$ phase with time and temperature is correlated to the stability of phases from the $\mathrm{Cu}-\mathrm{Zn}$ system (Fig. 5). According to calculations using ThermoCalc, the $\gamma$ phase that is $\mathrm{Cu}_{5} \mathrm{Zn}_{8}$ and $\mathrm{Al}_{4} \mathrm{Cu}_{9}$ (in the phase diagram of Al-Cu-Zn (Ref 13)) has the lowest Gibbs free energy (Fig. 5). At the top of the $\gamma$ phase 

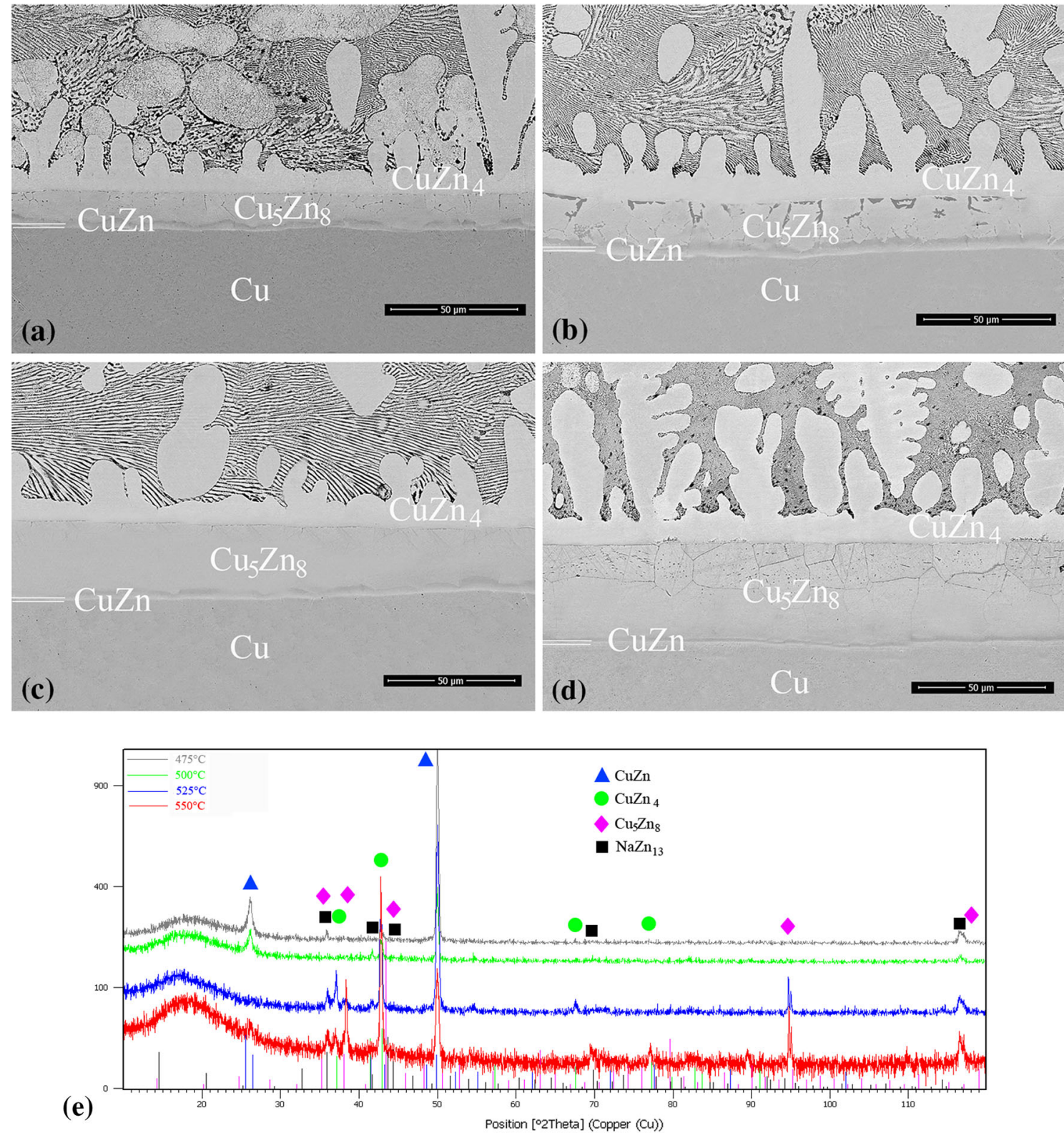

Fig. 4 Microstructure of interfaces on the cross-sections of $\mathrm{Zn}$ - $\mathrm{Al}$ with $0.5 \% \mathrm{Na}$ on a $\mathrm{Cu}$ substrate after spreading test for 8 min at the temperatures of (a) 475 , (b) 500 , (c) 525 , and (d) $550{ }^{\circ} \mathrm{C}$, and (e) XRD analysis results (starting from 475 on the top to $550{ }^{\circ} \mathrm{C}$ at the figure's bottom)

layers, due to the path of the fast diffusing $\mathrm{Cu}$ to solder, there appears to be what looks like microcracking in the microstructure (Fig. 4), and start in the formed $\mathrm{Al}_{4} \mathrm{Cu}_{9}$ phase, which was also confirmed by XRD analysis. The calculated activation energy for $\mathrm{Zn}-\mathrm{Al}+\mathrm{Na}$ alloys on $\mathrm{Cu}$ substrate is presented in Table 1. The highest value of activation energy of the $\gamma$ phases was obtained for $\mathrm{Zn}-\mathrm{Al}+1.0 \mathrm{Na}$ alloy $(89.62 \mathrm{~kJ} / \mathrm{mol})$ which is two times higher than those for eutectic $\mathrm{Zn}-\mathrm{Al}$ (Ref 2 ) and $\mathrm{Zn}$ $\mathrm{Al}+\mathrm{Cu}$ alloys (Ref 12), and also much higher than that for $\mathrm{Zn}$ $\mathrm{Al}+\mathrm{Ag}$ alloys (Ref 2). The activation energy of the $\varepsilon$ phase, rising with increasing $\mathrm{Na}$ content in the alloys, and for the $\mathrm{Zn}$ $\mathrm{Al}+0.5 \mathrm{Na}$ alloy, is on the same level $(\sim 29 \mathrm{~kJ} / \mathrm{mol})$ as for eutectic Zn-Al (Ref 2).

\subsection{Aging of Joints}

The samples (cross-sections) of $\mathrm{Zn}$-Al with $0.2,0.5$, and 1.0 $\mathrm{Na}$ content after soldering at $500{ }^{\circ} \mathrm{C}$ for $1 \mathrm{~min}$ were aged for 1 , 10 , and 30 days at the temperatures of 120,170 , and $250{ }^{\circ} \mathrm{C}$. The samples were chosen after soldering for $1 \mathrm{~min}$, to show the effect of aging time and temperature for changes to IMCs occurring at the interface. The obtained microstructures after aging were similar for all $\mathrm{Zn}-\mathrm{Al}+\mathrm{Na}$ alloys, with only the thickness of layers at the interface differing with changes to $\mathrm{Na}$ content. The microstructures of $\mathrm{Zn}-\mathrm{Al}+1.0 \mathrm{Na}$, after aging at $120{ }^{\circ} \mathrm{C}$ for 1,10 , and 30 days, are presented in Fig. 6. The two layers are observed at the interface, $\varepsilon\left(\mathrm{CuZn}_{4}\right)$ and $\gamma\left(\mathrm{Cu}_{5} \mathrm{Zn}_{8}\right.$ and $\left.\mathrm{Al}_{4} \mathrm{Cu}_{9}\right)$, which grow as time increases. In the $\gamma$ layer, fast 


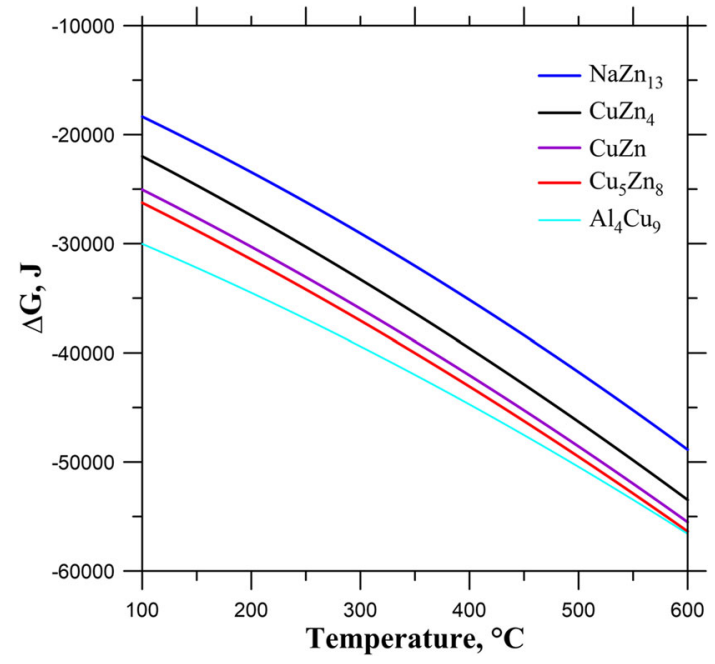

Fig. 5 Temperature dependencies of Gibbs free energy of IMCs, calculated by ThermoCalc

Table 1 Activation energy of IMCs of $\mathrm{Zn}$-Al alloys with Na content after soldering

\begin{tabular}{lcc}
\hline Alloys & IMCs & Activation energy, $\boldsymbol{Q}, \mathbf{k J} / \mathbf{m o l}$ \\
\hline \multirow{2}{*}{$\mathrm{Zn}-\mathrm{Al}(\mathrm{Ref} 2)$} & $\mathrm{CuZn}$ & 32.38 \\
& $\mathrm{Cu}_{5} \mathrm{Zn}_{8}$ & 42.38 \\
& $\mathrm{CuZn}_{4}$ & 29.54 \\
$\mathrm{Zn}-\mathrm{Al}+0.2 \mathrm{Na}$ & $\mathrm{CuZn}$ & 59.71 \\
& $\mathrm{Cu}_{5} \mathrm{Zn}_{8}$ & 58.10 \\
& $\mathrm{CuZn}_{4}$ & 13.15 \\
$\mathrm{Zn}-\mathrm{Al}+0.5 \mathrm{Na}$ & $\mathrm{CuZn}$ & 19.72 \\
& $\mathrm{Cu}_{5} \mathrm{Zn}_{8}$ & 80.94 \\
$\mathrm{Zn}-\mathrm{Al}+1.0 \mathrm{Na}$ & $\mathrm{CuZn}_{4}$ & 29.22 \\
& $\mathrm{CuZn}$ & 34.08 \\
& $\mathrm{Cu}_{5} \mathrm{Zn}_{8}$ & 89.62 \\
& $\mathrm{CuZn}_{4}$ & 56.02 \\
\hline
\end{tabular}

diffusion of the $\mathrm{Cu}$ path formed during soldering created particles of $\mathrm{Al}_{4} \mathrm{Cu}_{9}$ and grew, as confirmed by EDS analysis (Table 2). The diffusion rate of the $\mathrm{Al}$ element in the $\mathrm{Cu}$ substrate is slightly higher than that of the $\mathrm{Zn}$ element in the $\mathrm{Cu}$ substrate (Ref 16). The calculated diffusion rates of $\mathrm{Al}$ and $\mathrm{Zn}$ elements in the $\mathrm{Cu}$ substrate at $450{ }^{\circ} \mathrm{C}$ are $5.3 \times 10^{14}$ and $3.9 \times 10^{14} \mathrm{~cm}^{2} / \mathrm{s}$, respectively (Ref 16). According to Fig. 5, the Gibbs free energy of the $\mathrm{Al}_{4} \mathrm{Cu}_{9}$ phase is lower than that for the $\mathrm{Cu}_{5} \mathrm{Zn}_{8}$ phase, and at lower temperatures this difference becomes more marked. However, for aging at $170{ }^{\circ} \mathrm{C}$ (Fig. 7), after 1 day (Fig. 7a), a microstructure similar to that after $120{ }^{\circ} \mathrm{C}$ was observed in the $\varepsilon$ and $\gamma$ layers, with increasing particles of $\mathrm{Al}_{4} \mathrm{Cu}_{9}$ in the $\gamma$ phase. But after 10 days (Fig. 7b) the microstructure changed, the $\varepsilon$ phase was consumed by the $\gamma$ phase, and particles of $\mathrm{Al}_{4} \mathrm{Cu}_{9}$ phase dissolved in $\mathrm{Cu}_{5} \mathrm{Zn}_{8}$. This effect is associated with increasing the temperature to $170{ }^{\circ} \mathrm{C}$, which caused increasing diffusion of $\mathrm{Cu}$ to the solder and a greater amount of free $\mathrm{Zn}$, which created a $\mathrm{Cu}_{5} \mathrm{Zn}_{8}$ layer with Al dissolving inside. A similar effect was observed by Wang (Ref 17) for $\mathrm{SnZn}$ on $\mathrm{Cu}$, for aging at $170{ }^{\circ} \mathrm{C}$, though the highest stability of the $\mathrm{Cu}_{5} \mathrm{Zn}_{8}$ layer with increased time caused the creation of a $\mathrm{Cu}_{6} \mathrm{Sn}_{5}$ phase. This was caused by the diffusion of $\mathrm{Cu}$ to the solder and the availability of $\mathrm{Sn}$ at the
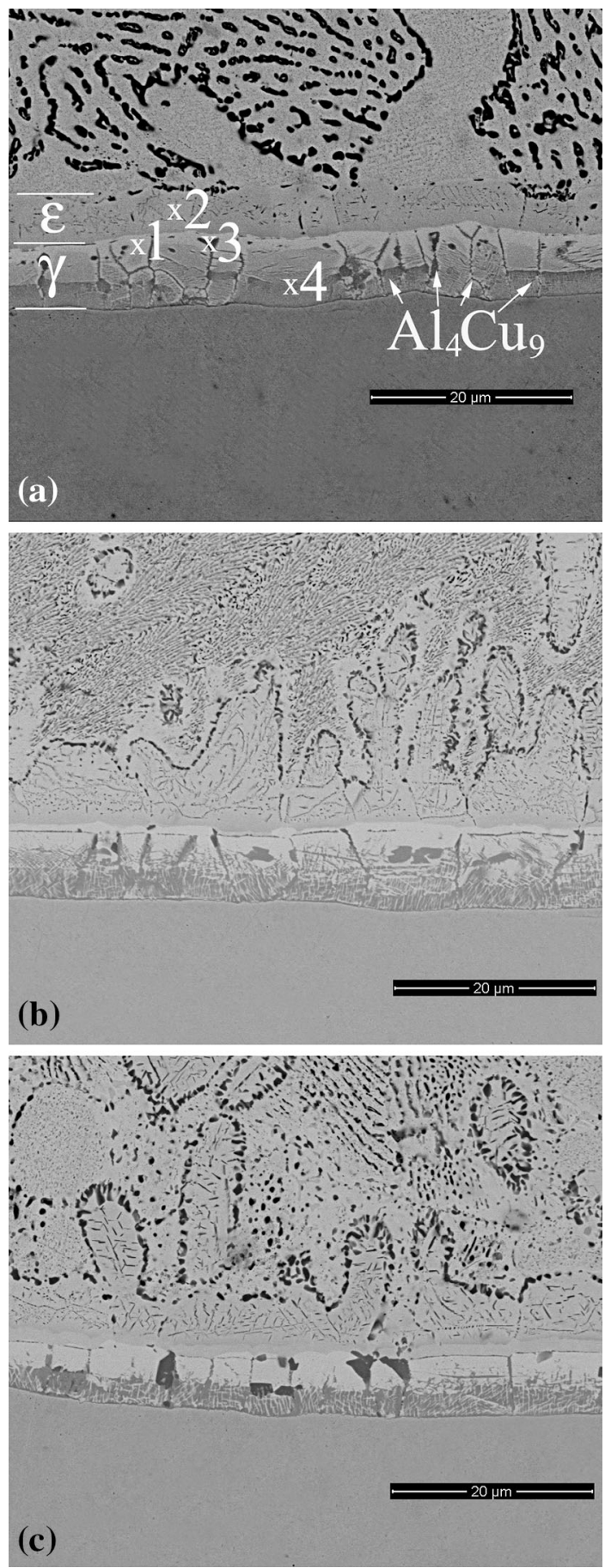

Fig. 6 Microstructure of $\mathrm{Zn}-\mathrm{Al}+1.0 \mathrm{Na}$ after aging process at a temperature of $120^{\circ} \mathrm{C}$ for (a) 1 , (b) 10 , and (c) 30 days

interface. After 30 days (Fig. 7c), the thickness of the $\mathrm{Cu}_{5} \mathrm{Zn}_{8}$ layer grew, and the microstructure was almost the same as that after 10 days. On increasing the aging temperature to $250{ }^{\circ} \mathrm{C}$, the $\gamma-\mathrm{Cu}_{5} \mathrm{Zn}_{8}$ layer grew much faster, resulting in a $\gamma$ layer several times thicker than that obtained by aging at $170{ }^{\circ} \mathrm{C}$ for the same time. The microstructures of $\mathrm{Zn}-\mathrm{Al}+1.0 \mathrm{Na}$, after aging at $250{ }^{\circ} \mathrm{C}$, are presented in Fig. 8(a), (b), and (c) for 1, 10 , and 30 days, respectively. At the interface, in the $\gamma-\mathrm{Cu}_{5} \mathrm{Zn}_{8}$ layer, and at the top, close to the solder drop, particles of the 
Table 2 EDS analysis of $\mathrm{Zn}-\mathrm{Al}+1.0 \mathrm{Na}$ at the points marked in Fig. 6 and 7

\begin{tabular}{lrcc}
\hline Marked point & Al, at.\% & Cu, at.\% & Zn, at.\% \\
\hline 1 & 9.8 & 41.7 & 48.6 \\
2 & 0.7 & 17.6 & 81.7 \\
3 & 22.2 & 46.9 & 30.9 \\
4 & 11.7 & 45.2 & 43.1 \\
5 & 55.3 & 34.3 & 10.4 \\
6 & 9.5 & 40.5 & 50.0 \\
7 & 34.0 & 41.4 & 24.6 \\
8 & 3.2 & 34.5 & 62.3 \\
\hline
\end{tabular}

$\mathrm{Al}_{4} \mathrm{Cu}_{9}$ phase are observed. In the EDS analysis, the $\mathrm{Na}$ was not taken into consideration, because the $\mathrm{Zn}^{\mathrm{L}}$ and $\mathrm{Na}^{\mathrm{K}}$ appear close to each other, and therefore the EDS analysis of $\mathrm{Na}$ was not reported in Table 2. The initial thickness of each IMC layer after the aging process should be taken into account, and in Eq 1 should be modified as

$\Delta x=d_{0}+k t^{n}$,

where $\Delta x$ is the average thickness of the IMC layer, $d_{0}$ is the initial thickness of the IMC layer, $k$ is the growth rate coefficient, and $t$ is the aging duration.

The dependencies of thickness of the $\gamma$ layer versus time for $\mathrm{Zn}-\mathrm{Al}+\mathrm{Na}$ alloys are shown in Fig. 9, for the temperatures of (a) 120 , (b) 170 , and (c) $250^{\circ} \mathrm{C}$. At higher aging temperature, the $\gamma$ layer grew faster, but with the addition of increased $\mathrm{Na}$ content to $\mathrm{Zn}-\mathrm{Al}$ alloys the thickness of IMC layer is reduced. This effect was caused by $\mathrm{Zn}$ bonded with $\mathrm{Na}$ and forming $\mathrm{NaZn}_{13}$ precipitates, which block the growth of the $\gamma$ layer at the interface. The formation of the $\mathrm{NaZn}_{13}$ phase was confirmed by XRD analysis. The thickness of the IMC layer for Zn-Al-Na alloys at the interface after aging was less than the values for $\mathrm{Zn}-4 \mathrm{Al}$ obtained by Takaku et al. (Ref 12). The three $\beta, \varepsilon$, and $\gamma$ phases' layers were observed in Ref 12 after annealing, even at temperatures as high as 200 and $300{ }^{\circ} \mathrm{C}$. For the $\mathrm{Zn}-\mathrm{Al}+\mathrm{Na}$ alloys on $\mathrm{Cu}$ substrate at high temperatures, only the $\gamma$ phase was observed and grew. The obtained growth rates for the $\mathrm{Zn}-\mathrm{Al}+\mathrm{Na} \gamma$ phase (Table 3), compared with $\mathrm{Zn}$ $\mathrm{Al}$ and $\mathrm{Zn}-\mathrm{Al}+\mathrm{Cu}$ (Ref 12), are orders of magnitude smaller for each temperature. The activation energy for the $\gamma$ phase was also much higher for the $\mathrm{Zn}-\mathrm{Al}+\mathrm{Na}$, at $65.69,66.20$, and $73.11 \mathrm{~kJ} / \mathrm{mol}$ for $0.2,0.5$, and $1.0 \mathrm{wt} . \% \mathrm{Na}$ content, compared to $44.37 \mathrm{~kJ} / \mathrm{mol}$ for $\mathrm{Zn}-4 \mathrm{Al}$ (Ref 12) and $39.03 \mathrm{~kJ} / \mathrm{mol}$ for $\mathrm{Zn}$ $4 \mathrm{AllCu}$ (Ref 12). Taking into account the growth rate and activation energy data obtained from the aging process, it can be said that the amount of $\mathrm{Na}$ in $\mathrm{Zn}-\mathrm{Al}$ alloys influences the number of $\mathrm{NaZn}_{13}$ precipitates at the interface, and also has a great impact on phenomena occurring there.
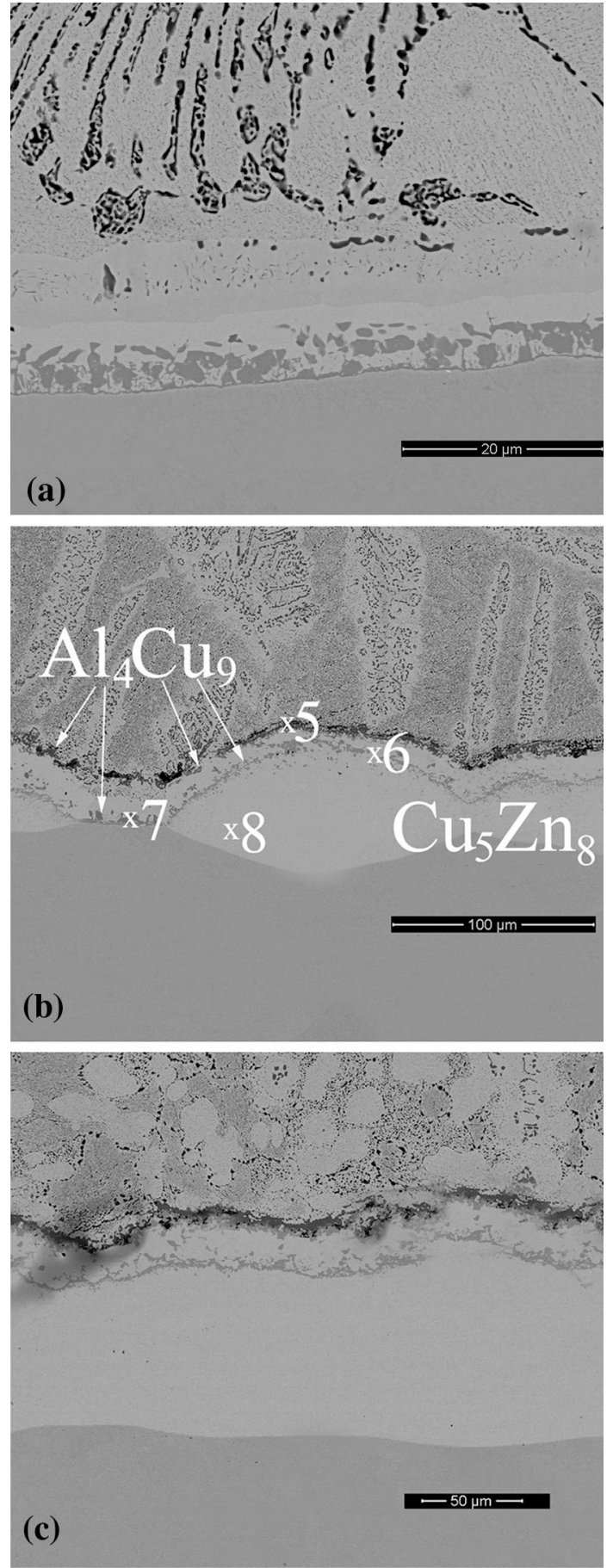

Fig. 7 Microstructure of $\mathrm{Zn}-\mathrm{Al}+1.0 \mathrm{Na}$ after aging process at a temperature of $170{ }^{\circ} \mathrm{C}$ for (a) 1 , (b) 10 , and (c) 30 days 

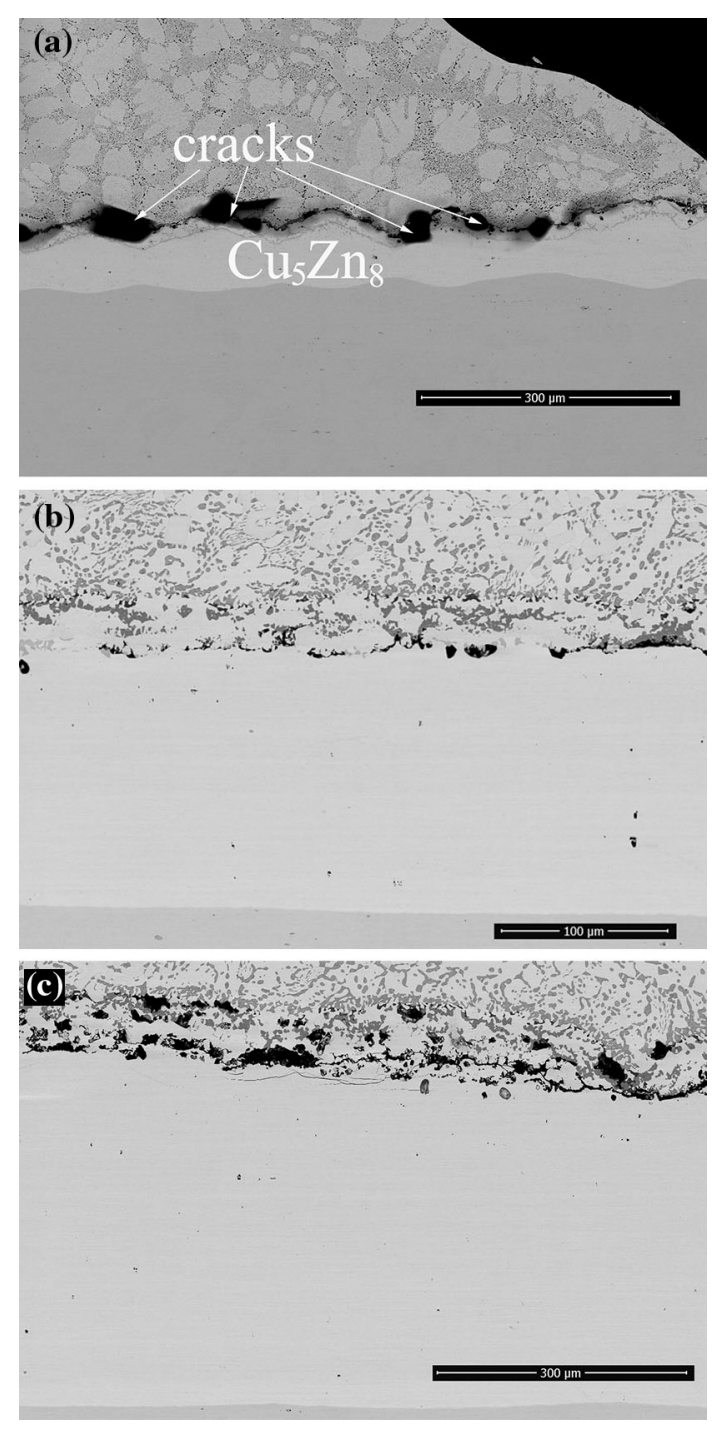

Fig. 8 Microstructure of $\mathrm{Zn}-\mathrm{Al}+1.0 \mathrm{Na}$ after aging process at a temperature of $250{ }^{\circ} \mathrm{C}$ for (a) 1 , (b) 10 , and (c) 30 days

\section{Conclusions}

The effects of spreading time and temperature on the creation of IMC layers of lead-free $\mathrm{Zn}-\mathrm{Al}-\mathrm{xNa}$ solder alloys on $\mathrm{Cu}$ substrates were investigated. The addition of $0.2 \% \mathrm{Na}$ to $\mathrm{Zn}-\mathrm{Al}$ caused the spreading area to expand, while the addition of greater amounts of $\mathrm{Na}$ did not cause any further expansion of the spreading area. Increasing $\mathrm{Na}$ content in $\mathrm{Zn}-\mathrm{Al}$ alloys caused the growth rate of the $\mathrm{Cu}_{5} \mathrm{Zn}_{8}$ phase to remain constant, the $\mathrm{CuZn} \mathrm{n}_{4}$ phase to decrease, and the $\mathrm{CuZn}$ phase to increase, over time, at $500{ }^{\circ} \mathrm{C}$. The growth of IMCs during soldering on the $\mathrm{Cu}$ substrate was found to be controlled by volume diffusion for $\mathrm{CuZn}$ and $\mathrm{CuZn} \mathrm{n}_{4}$ phases, but by mixed volume diffusion and chemical reaction for the $\mathrm{Cu}_{5} \mathrm{Zn}_{8}$ phase. Higher activation energies were observed compared to eutectic $\mathrm{Zn}-\mathrm{Al}$, and the activation energy increased with increasing $\mathrm{Na}$ content in $\mathrm{Zn}-\mathrm{Al}$ alloys. In the spreading test, the thickness of IMC layers for all $\mathrm{ZnAl}+\mathrm{Na}$ alloys increased with increased time and temperature. The higher growth of the $\gamma$ layer was observed, as was the fast diffusion path of $\mathrm{Cu}$ that started to create the $\mathrm{Al}_{4} \mathrm{Cu}_{9}$ phase,
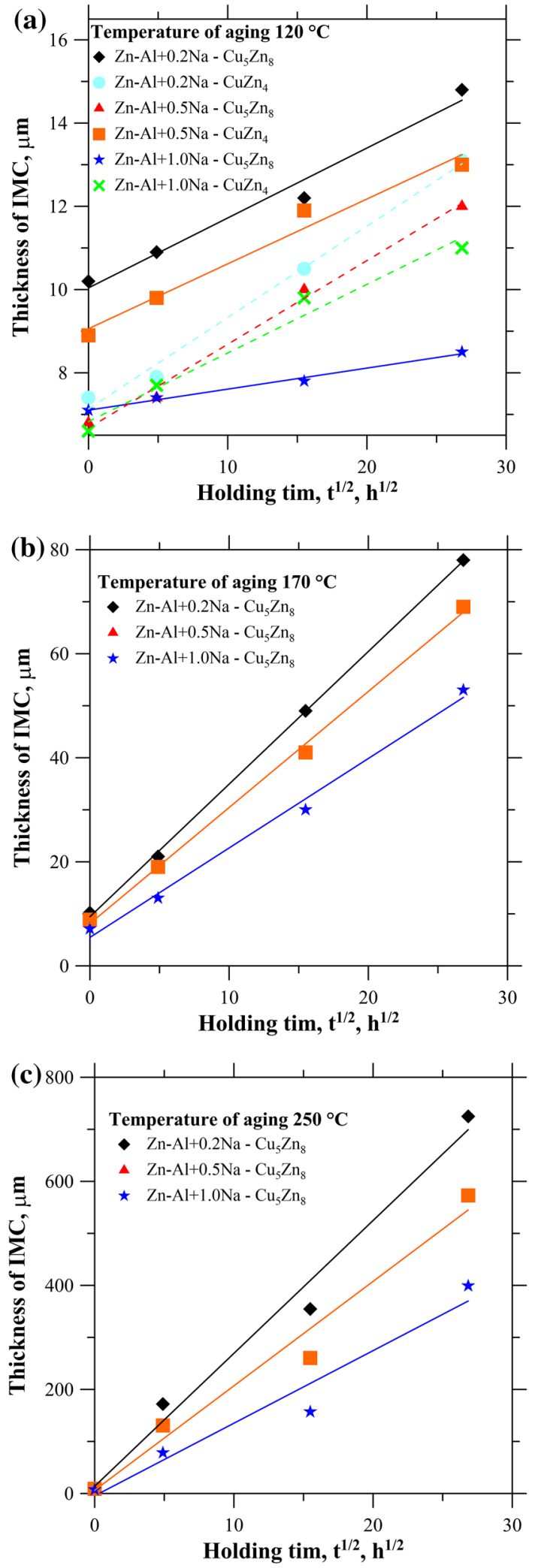

Fig. 9 Dependencies of IMC layer thickness vs. time for $\mathrm{Zn}$ $\mathrm{Al}+\mathrm{Na}$ alloys after aging process at the temperatures of (a) 120, (b) 170 , and (c) $250{ }^{\circ} \mathrm{C}$

which has a lower Gibbs free energy phase (Ref 2). During the aging process, the growth of IMC layers was controlled by volume diffusion. At $120^{\circ} \mathrm{C}$, the $\varepsilon$ and $\gamma$ layers were observed, 
Table 3 Properties of IMC growth during aging in $\mathrm{Cu} / \mathrm{Solid} \mathrm{Zn}$-Al alloys with Na additions

\begin{tabular}{|c|c|c|c|c|c|c|}
\hline \multirow[b]{2}{*}{ Solder } & \multirow[b]{2}{*}{ IMC } & \multicolumn{3}{|c|}{$K, \mathrm{~m} \mathrm{~s}^{1 / 2}$} & \multirow[b]{2}{*}{$k_{0}, \mathrm{~m} \mathrm{~s}^{1 / 2}$} & \multirow[b]{2}{*}{ Activation energy, $Q, \mathrm{~kJ} / \mathrm{mol}$ ) } \\
\hline & & $120^{\circ} \mathrm{C}$ & $170^{\circ} \mathrm{C}$ & $250{ }^{\circ} \mathrm{C}$ & & \\
\hline $\mathrm{Zn}-\mathrm{Al}+0.2 \mathrm{Na}$ & $\mathrm{Cu}_{5} \mathrm{Zn}_{8}$ & $1.68 \mathrm{E}-10$ & $2.55 \mathrm{E}-09$ & $2.55 \mathrm{E}-08$ & $1.06 \mathrm{E}-01$ & 65.69 \\
\hline $\mathrm{Zn}-\mathrm{Al}+0.5 \mathrm{Na}$ & & $1.56 \mathrm{E}-10$ & $2.23 \mathrm{E}-09$ & $2.46 \mathrm{E}-08$ & $1.13 \mathrm{E}-01$ & 66.20 \\
\hline $\mathrm{Zn}-\mathrm{Al}+1.0 \mathrm{Na}$ & & $5.05 \mathrm{E}-11$ & $1.72 \mathrm{E}-09$ & $1.40 \mathrm{E}-08$ & $3.75 \mathrm{E}-01$ & 73.11 \\
\hline
\end{tabular}

and inside the $\gamma$ layer there was a particle of the $\mathrm{Al}_{4} \mathrm{Cu}_{9}$ phase, which increased over time. At higher temperatures (170 and $250{ }^{\circ} \mathrm{C}$ in particular), the $\gamma$ layer thickness grew rapidly, and the small number of particles in the $\mathrm{Al}_{4} \mathrm{Cu}_{9}$ phase was observed only in the top of the $\mathrm{Cu}_{5} \mathrm{Zn}_{8}$ layer. Increasing the $\mathrm{Na}$ content in the $\mathrm{Zn}-\mathrm{Al}$ alloy caused an increasing number of $\mathrm{NaZn}_{13}$ precipitates, which had a great impact on the creation of IMC layers of leadfree $\mathrm{Zn}-\mathrm{Al}-x \mathrm{Na}$ solder alloys.

\section{Acknowledgments}

This work was financed by the Minister of Science and High Education of Poland Grant IP2014 011473, in the years 20152017.

\section{Open Access}

This article is distributed under the terms of the Creative Commons Attribution 4.0 International License (http://creativecommons.org/ licenses/by/4.0/), which permits unrestricted use, distribution, and reproduction in any medium, provided you give appropriate credit to the original author(s) and the source, provide a link to the Creative Commons license, and indicate if changes were made.

\section{References}

1. T. Gancarz, G. Cempura, and W. Skuza, Characterization of ZnAl Cast Alloys with Na Additions, Mater. Character, 2016, 111, p 147-153

2. T. Gancarz, J. Pstruś, P. Fima, and S. Mosińska, Effect of Ag Addition to Zn-12Al Alloy on Kinetics of Growth of Intermediate Phases on $\mathrm{Cu}$ Substrate, J. Alloys Compd., 2014, 582, p 313-322
3. X. Yan, S. Liu, W. Long, J. Huang, L. Zhang, and Y. Chen, The Effect of Homogenization Treatment on Microstructure and Properties of ZnAl15 Solder, Mater. Des., 2013, 45, p 440-445

4. T. Gancarz, J. Pstruś, S. Mosińska, and S. Pawlak, Effect of $\mathrm{Cu}$ Addition to Zn-12Al Alloy on Thermal Properties and Wettability on $\mathrm{Cu}$ and Al Substrates, Met. Mater. Trans. A, 2016, 47, p 368-377

5. T. Gancarz, J. Pstruś, P. Fima, and S. Mosińska, Thermal Properties and Wetting Behavior of High Temperature Zn-Al-In Solders, J. Mater. Eng. Perform., 2012, 21, p 599-605

6. X. Yang, W. Hu, X. Yan, and Y. Lei, Microstructure and Solderability of Zn-6Al-xSn Solders, J. Electron. Mater., 2015, 44, p 1128-1133

7. N. Kang, H. Na, S. Kim, and C. Kang, Alloy design of Zn-Al-Cu Solder for Ultra High Temperatures, J. Alloys Compd., 2009, 467, p 246-250

8. F. Ji, S. Xue, J. Lou, Y. Lou, and S. Wang, Microstructure and Properties of $\mathrm{Cu} / \mathrm{Al}$ Joints Brazed with Zn-Al Filler Metals, Trans. Nonferrous Met. Soc. China, 2012, 22, p 281-287

9. L. Ma, D. He, X. Li, and J. Jiang, High-Frequency Induction Soldering of Magnesium Alloy AZ31B Using a Zn-Al Filler Metal, Mater. Lett., 2010, 64, p 596-598

10. Y. Jinlong, X. Songbai, X. Peng, L. Zhaoping, D. Wei, and Z. Junxiong, Development of Novel CsF-RbF-AlF3 Flux for Brazing Aluminium to Stainless Steel with Zn-Al Filler Metal, Mater. Des., 2014, 64, p 110-115

11. M. Prach and R. Kolenak, Soldering of Copper with High-Temperature Zn-Based Solders, Procedia Eng., 2015, 100, p 1370-1375

12. Y. Takaku, L. Felicia, I. Ohnuma, R. Kainuma, and K. Ishida, Interfacial Reaction Between $\mathrm{Cu}$ Substrates and $\mathrm{Zn}-\mathrm{Al}$ Base HighTemperature Pb-Free Solders, J. Electron. Mater., 2008, 37, p 314-323

13. V. Raghavan, Al-Cu-Zn, J. Phase Equilib. Diff., 2007, 28, p 183-188

14. X. Liu, B. Doung, D. Zhao, and X. Zhu, Microstructures and Properties of Tungsten Inert Gas Welding Joint of Super-Eutectic ZA Alloy, Trans. Nonferrous Met. Soc. China, 2001, 11, p 387-390

15. J. Pstrus and T. Gancarz, Interfacial Phenomena in $\mathrm{Al} / \mathrm{Al}, \mathrm{Al} / \mathrm{Cu}$, and $\mathrm{Cu} / \mathrm{Cu}$ Joints Soldered Using an Al-Zn Alloy with $\mathrm{Ag}$ or $\mathrm{Cu}$ Additions, J. Mater. Eng. Perform., 2014, 23, p 1614-1624

16. Y. Xiao, M. Li, L. Wang, S. Huang, X. Du, and Z. Liu, Interfacial Reaction Behavior and Mechanical Properties of Ultrasonically Brazed $\mathrm{Cu} / \mathrm{Zn}-\mathrm{Al} / \mathrm{Cu}$ Joints, Mater. Des., 2015, 73, p 42-49

17. J. Wang, C. Lin, and C. Chen, Retarding the Cu5Zn8 Phase Fracture at the $\mathrm{Sn}-9$ wt $\% \mathrm{Zn} / \mathrm{Cu}$ Interface, Scr. Mater., 2011, 64, p 633-636 